\title{
Decentralizing treatment services with link ART centres- experience from Karnataka, South India
}

\author{
Salma Fahim ${ }^{1 *}$, Suresh Shastri ${ }^{1}$, Bharat Rewari ${ }^{2}$ \\ From 17th International Symposium on HIV and Emerging Infectious Diseases (ISHEID) \\ Marseille, France. 23-25 May 2012
}

\section{Background}

Prior to 2007-08, ART services in Karnataka state, India were delivered through ART centres, located mainly in medical colleges, and tertiary and district hospitals. This led to high rates of defaults, increased travel time and cost and loss of working hours. To make treatment services more accessible to PLHIV, link ART centres (LACs) were developed at sub-district primary and secondary care levels, co-located with HIV voluntary counselling and testing centres.

\section{Methods}

After a thorough needs assessment based on existing ART and HIV testing data which included load in ART centre, HIV prevalence, distance and accessibility, sites were identified, health personnel trained, and patients sensitized about the centres.

\section{Results}

Currently there are 122 LACs attached to 29 nodal ART centres in the state. The LACs provide services to 5,498 PLHIV.Default rate has come down from $3.5 \%$ in ART centres to less than $0.5 \%$ in LACs.The average patient travel distance has declined from 70 to $30 \mathrm{kms}$, saving travel cost and time. Waiting times for refilling prescriptions have declined from four hours to one hour, which has improved patient adherence. Health care staff at primary and secondary level care centres are gradually taking the lead in HIV care and treatment service delivery.

\section{Conclusions}

The establishment of LACs at primary and secondary care levels has helped improve drug adherence and service access. They save travel cost and time, and more importantly, help strengthen primary and secondary

${ }^{1}$ Karnataka State Aids Prevention Society, Bangalore, India

Full list of author information is available at the end of the article health care services, which is beneficial for program sustainability.

\section{Author details \\ ${ }^{1}$ Karnataka State Aids Prevention Society, Bangalore, India. ${ }^{2}$ National AIDS Control Organisation, India.}

Published: 25 May 2012

doi:10.1186/1742-4690-9-S1-P82

Cite this article as: Fahim et al: Decentralizing treatment services with link ART centres- experience from Karnataka, South India. Retrovirology 2012 9(Suppl 1):P82.
Submit your next manuscript to BioMed Central and take full advantage of:

- Convenient online submission

- Thorough peer review

- No space constraints or color figure charges

- Immediate publication on acceptance

- Inclusion in PubMed, CAS, Scopus and Google Scholar

- Research which is freely available for redistribution
C Biomed Central 